\title{
The Effect of Celebrity Endorser on The Customer's Online Purchase Intention (Case Study on Food and Beverage MSME Products in Denpasar)
}

\author{
Ade Ruly Sumartini ${ }^{1 *}$, I. A. Cynthia Saisaria Mandasari ${ }^{2}$ \\ ${ }^{1}$ Universitas Warmadewa, Denpasar-Bali, Indonesia \\ \{aderuly81@gmail.com $\left.{ }^{1}\right\}$
}

\begin{abstract}
This research aims to determine the effect of celebrity endorsers on online purchase intentions. The population is the people in Denpasar City using purposive sampling. The data analysis technique used multiple regression analysis. It was found that attractiveness, trustworthiness and expertise, influence simultaneously and partially on the purchase intention in food and beverage MSME products in Denpasar City. If before the Covid 19 pandemic conditions consumers were still hesitant to buy food and beverage products online, it is hoped that using celebrity endorsers that display food and beverage products in a real and honest manner, can increase the purchase intention of consumers who previously were still hesitant to buy food and beverage products by online. With the increase in consumer purchase intentions, it is also hoped that MSME players who sell food and beverages online can increase their sales turnover significantly.
\end{abstract}

Keyword : Celebrity, Customer's, Products.

\section{Introduction}

Micro, small and medium enterprises (MSMEs) are the most numerous business groups. Micro, small and medium enterprises (MSMEs) have an important and strategic role for the economic growth of countries, both developing and developed countries. When the economic crisis took place in Indonesia, the ability of MSMEs to survive during the economic crisis was proof that the MSME sector was part of a fairly resilient business sector. The micro, small and medium enterprises sector that is mostly chosen by MSMEs is culinary. Business in the culinary field is considered promising because food is one of the basic human needs [1]. [2] found that establishing food businesses could help the government to reduce unemployment and absorb labor and at the same time increase the income received by the community, especially MSME entrepreneurs.

Since several years ago, the business development in the food and beverage sector has experienced very significant growth. The restaurant and restaurant industry is still believed to be a form of business that has good prospects, even in crisis conditions. However, currently there has been a Covid-19 pandemic, where in Indonesia the Covid-19 virus first entered on March 2, 2020. This pandemic has caused a decline in economies around the world, so that it has a very pronounced impact on MSMEs, where there are many restaurants who went out of business, because they were unable to maintain the number of visitors. The decline in the number of consumers in the Covid-19 pandemic was due to decreased activities outside the 
home (social distance) to minimize the spread of the Covid-19 virus. To return to success in the food and beverage sector is not only determined by the number of visitors, but also by the ability to increase customer growth. In an effort to increase customer growth from a business, nowadays an e-marketing strategy is needed that can increase the intention to buy a product. One strategy that can be done is to use Celebgram or Celebrity Endorser. This strategy is related to efforts to increase purchase intention online. In the initial survey, it was found that consumers' purchase intentions online still had several obstacles such as the quality (in the form of taste) of food and beverage products that did not match expectations, so in this case it was deemed necessary to use celebrity endorsers in increasing purchase intentions online for food and beverages offered by MSMEs in Denpasar.

Based on the background description the formulation of the problem in this study is arranged as follows:

H1: Attractiveness, Trustworthiness and Expertise have a significant positive effect on the online purchase intention in food and beverage MSME products.

$\mathrm{H} 2$ : Attractiveness has a significant positive effect on the online purchase intention in food and beverage MSME products.

H3: Trustworthiness has a significant positive effect the online purchase intention in food and beverage MSME products.

H4: Expertise has a significant positive effect on the online purchase intention in food and beverage MSME products.

\section{Method}

Based on the problems studied, the variables in the study are Attractiveness, Trustworthiness, Expertise and purchase intention. Data collection used in this study includes interviews and questionnaires. The data that has been collected will be processed using descriptive statistical analysis techniques. Finally, the interpretation of each variable is carried out to see the suitability of the theoretical and empirical models so that conclusions can be drawn from the formulation of the research problem. The research location in this study is in the city of Denpasar. As for the object of research is the behavior of consumers in Denpasar City who intend to buy food and beverage MSME products that are influenced by Celebrity Endorsers. The population in this study is the people of Denpasar City. Determination of the sample of respondents using a non-probability sampling method with purposive sampling technique, with the criteria that consumers have a minimum high school education because at this level of education it is considered that they already have good knowledge and are able to understand every question in the questionnaire and have never purchased MSME food products and drinks online. The sample in this study were 100 respondents.

\section{Result And Discussion}

Table 1. Test Of Normality

\begin{tabular}{ccccccc}
\hline & \multicolumn{3}{c}{ Kolmogorov-Smirnov $^{\mathbf{a}}$} & \multicolumn{3}{c}{ Shapiro-Wilk } \\
\cline { 2 - 7 } Total_Y1 & Statistic & Df & Sig. & Statistic & Df & Sig. \\
& .147 & 100 & .200 & .932 & 100 & .171 \\
\hline
\end{tabular}


Judging from the results of the Shapiro-Wilk data processing, the significant value (probability value) obtained is 0.171 greater than $0.05(0.171>0.05)$, it can be said that the variables in this study are normally distributed.

Table 2. Test of Multicollinearity

\begin{tabular}{|c|c|c|c|c|c|c|c|c|}
\hline \multirow{3}{*}{\multicolumn{2}{|c|}{ Model }} & & & \multirow{3}{*}{$\begin{array}{c}\text { Coefficients }^{\mathbf{a}} \\
\text { Standardized } \\
\text { Coefficients } \\
\text { Beta } \\
\end{array}$} & \multirow[b]{3}{*}{$\mathbf{T}$} & \multirow[b]{3}{*}{ Sig. } & \multirow{2}{*}{\multicolumn{2}{|c|}{$\begin{array}{c}\text { Collinearity } \\
\text { Statistics }\end{array}$}} \\
\hline & & \multicolumn{2}{|c|}{$\begin{array}{l}\text { Unstandardized } \\
\text { Coefficients }\end{array}$} & & & & & \\
\hline & & B & Std. Error & & & & Tolerance & VIF \\
\hline 1 & $\begin{array}{c}\text { (Constant } \\
\text { ) }\end{array}$ & .431 & .949 & & .454 & .651 & & \\
\hline & Total_X1 & .216 & .093 & .181 & 2.320 & .022 & .629 & 1.591 \\
\hline & Total_X2 & .319 & .067 & .372 & 4.761 & .000 & .629 & 1.589 \\
\hline & Total_X3 & .321 & .069 & .385 & 4.635 & .000 & .557 & 1.794 \\
\hline & Dependent & iable: ' & al_Y1 & & & & & \\
\hline
\end{tabular}

The test results for the multicollinearity test shown that the Tolerance value of each independent variable, namely Attractiveness is 0.629, Trustworthiness is 0.629 and Expertise is 0.557 where the value is above 0.1 while the VIF results show that for each independent variable is Attractiveness of 1.591, Trustworthiness of 1.589 and Expertise of 1.794 which has a value below 10. From these results it can be concluded that there is no multicollinearity symptom between the independent variables in the regression model.

Table 3. Test of Heteroscedasticity

\begin{tabular}{|c|c|c|c|c|c|c|c|c|}
\hline \multirow{3}{*}{\multicolumn{2}{|c|}{ Model }} & \multicolumn{5}{|c|}{ Coefficients $^{\mathrm{a}}$} & & \\
\hline & & \multicolumn{2}{|c|}{$\begin{array}{l}\text { Unstandardized } \\
\text { Coefficients }\end{array}$} & \multirow{2}{*}{$\begin{array}{c}\text { Standardized } \\
\text { Coefficients } \\
\text { Beta }\end{array}$} & \multirow[b]{2}{*}{$\mathbf{t}$} & \multirow[b]{2}{*}{ Sig. } & \multicolumn{2}{|c|}{$\begin{array}{c}\text { Collinearity } \\
\text { Statistics }\end{array}$} \\
\hline & & B & Std. Error & & & & Tolerance & VIF \\
\hline \multirow[t]{4}{*}{1} & (Constant) & 2.206 & .560 & & 3.940 & .000 & & \\
\hline & Total_X1 & -.002 & .055 & -.004 & -.030 & .976 & .629 & 1.591 \\
\hline & Total_X2 & -.060 & .040 & -.188 & $\begin{array}{c}- \\
1.510\end{array}$ & .134 & .629 & 1.589 \\
\hline & Total_X3 & -.024 & .041 & -.079 & -.593 & .555 & .557 & 1.794 \\
\hline a. 1 & ependent V & ble: RF & & & & & & \\
\hline
\end{tabular}

The test results for the Heteroscedasticity shown that the significance of each independent variable, namely Attractiveness is 0.976, Trustworthiness is 0.134 and Expertise is 0.555 where the value is above 0.05 , it can be concluded that there are no symptoms of Heteroscedasticity in the regression model used. 
Table 4. Regression result

\begin{tabular}{|c|c|c|c|c|c|c|c|c|}
\hline \multirow{2}{*}{\multicolumn{2}{|c|}{ Model }} & \multicolumn{2}{|c|}{$\begin{array}{l}\text { Unstandardized } \\
\text { Coefficients }\end{array}$} & \multirow{2}{*}{$\begin{array}{c}\text { Standardized } \\
\text { Coefficients } \\
\text { Beta } \\
\end{array}$} & \multirow[b]{2}{*}{$\mathbf{t}$} & \multirow[b]{2}{*}{ Sig. } & \multicolumn{2}{|c|}{ Collinearity Statistics } \\
\hline & & B & Std. Error & & & & Tolerance & VIF \\
\hline \multirow[t]{4}{*}{1} & $\begin{array}{c}\text { (Constant } \\
\text { ) }\end{array}$ & .431 & .949 & & .454 & .651 & & \\
\hline & Total_X1 & .216 & .093 & .181 & 2.320 & .022 & .629 & 1.591 \\
\hline & Total_X2 & .319 & .067 & .372 & 4.761 & .000 & .629 & 1.589 \\
\hline & Total_X3 & .321 & .069 & .385 & 4.635 & .000 & .557 & 1.794 \\
\hline
\end{tabular}

From the table above, it can be seen from the results of the regression analysis that the coefficient for the Attractiveness variable is 0.216, Trustworthiness is 0.319 and Expertise is 0.321 with a constant of 0.431 so that the regression equation model obtained is as follows:

$$
\mathrm{Y}=0.431+0.216 \mathrm{X}_{1}+0.319 \mathrm{X}_{2}+0.321 \mathrm{X}_{3}+\mathrm{e}
$$

The regression equation shows the direction of the influence of each independent variable (Attractiveness, Trustworthiness and Expertise) on the online purchase intention in food and beverage. . Based on this, it can be seen that the variables Attractiveness, Trustworthiness and Expertise have a positive influence on the online purchase intention in food and beverage. These results still need to be reviewed with the results of further statistical tests, namely the coefficient of determination and partial effect test of each independent variable on the dependent variable.

Table 5. Model Summary

\begin{tabular}{|c|c|c|c|c|c|c|c|c|c|}
\hline Model & $\mathbf{R}$ & $\begin{array}{c}\mathbf{R} \\
\text { Square }\end{array}$ & $\begin{array}{l}\text { Adjusted } \\
\text { R Square } \\
\end{array}$ & $\begin{array}{l}\text { Std. Error of } \\
\text { the Estimate }\end{array}$ & $\begin{array}{l}\text { R Square } \\
\text { Change }\end{array}$ & $\begin{array}{c}\text { Change } \\
\text { F } \\
\text { Change }\end{array}$ & $\begin{array}{l}\text { Statis } \\
\text { df1 }\end{array}$ & $\begin{array}{l}\text { tics } \\
\text { df2 } \\
\end{array}$ & $\begin{array}{c}\text { Sig. F } \\
\text { Change }\end{array}$ \\
\hline 1 & $.794^{\mathrm{a}}$ & .631 & .620 & 1.22137 & .631 & 54.742 & 3 & 96 & .000 \\
\hline \multicolumn{10}{|c|}{ Predictors: (Constant), Total_X3, Total_X2, Total_X1 } \\
\hline
\end{tabular}

The result of regression calculation shows that the adjusted $\mathrm{R}$ square value is 0.620 . This means that $62.00 \%$ of the variation in the purchase intention variable can be explained by the Attractiveness, Trustworthiness and Expertise variables, while the remaining $38 \%$ is explained by other variables not included in this research model

Table 6. F-Test

\begin{tabular}{ccccccc}
\hline \multicolumn{7}{c}{ ANOVA $^{\mathrm{a}}$} \\
& Model & Sum of Squares & df & Mean Square & F & Sig. \\
\hline 1 & Regression & 244.982 & 3 & 81.661 & 54.742 & $.000^{\mathrm{b}}$ \\
& Residual & 143.208 & 96 & 1.492 & & \\
& Total & 388.190 & 99 & & & \\
\hline
\end{tabular}


a. Dependent Variable: Total_Y1

b. Predictors: (Constant), Total_X3, Total_X2, Total_X1

For the $\mathrm{F}$ Test, the significance value is $0.000<0.05$, it can be concluded that simultaneously, the Attractiveness, Trustworthiness and Expertise variables simultaneously influence the purchase intention variable.

Attractiveness has a significant positive effect on the online purchase intention in food and beverage food and beverage of MSME products

The test results of the effect of Attractiveness on the online purchase intention in food and beverage food and beverage of MSME products, show that the $t$ value is 2.320 and the $p$ value ( $\mathrm{sig}$ ) is 0.022 which is below the alpha $0.05(0.022<0.05)$ which means that Attractiveness of celebrity endorser has a positive and significant effect on the online purchase intention in food and beverage food and beverage of MSME products. The beta value in the unstandardized coefficient of the Attractiveness variable shows a number of 0.216 , which means that if the Attractiveness variable is increased by one unit, the intention to buy food and beverage MSME products will increase by $21.6 \%$. The results of this study are supported by previous research where in the research of [3] the variables of attractiveness, trust, expertise, and price fairness have a positive and significant effect on purchase intention in the clothing sector. The attractiveness of this Celebrity Endorser increases the purchase intention of consumers because they are attracted by the way Celebrity Endorser displays products, place settings and also the title (caption) of the endorsed product.

Trustworthiness has a significant positive effect on the online purchase intention in food and beverage food and beverage of MSME products

The results of the test of the influence of Trustworthiness on the on the online purchase intention in food and beverage food and beverage of MSME products, show the $t$ value of 4.761 and a p value ( $\mathrm{sig}$ ) of 0.000 which is below the alpha of $0.05(0.000<0.05)$ which means that Trustworthiness towards celebrity endorser has a positive and significant effect on the online purchase intention in food and beverage food and beverage of MSME products. The beta value in the unstandardized coefficient of the Trustworthiness variable shows a number of 0.319 , which means that if the Trustworthiness variable is increased by one unit, the intention to buy food and beverage MSME products will increase by $31.9 \%$. The results of this study are supported by previous research where in the research of [4] found that there was a positive and significant influence between Celebrity Endorser and Brand Image on Purchase Intention of Etude House cosmetic products in Pelita Harapan Karawaci Tourism College students. In the influence of Celebrity Endorser Trustworthiness in increasing purchase intention from consumers seen from the level of consumer confidence in Celebrity Endorser which provides reality, honesty, suitability and impression so that consumers who have never made purchases online intend to buy the product.

Expertise (Expertise) has a significant positive effect on the online purchase intention in food and beverage food and beverage of MSME products

The results of the test of the effect of on the online purchase intention in food and beverage food and beverage of MSME products, show the t value of 4.635 and the $p$ value (sig) of 0.000 which is below the alpha of $0.05(0.000<0.05)$ which means that Expertise towards celebrity endorser has a positive and significant effect on the online purchase intention in food and beverage food and beverage of MSME products. The beta value in the unstandardized coefficient of the Expertise variable shows a figure of 0.321 , which means that if the Expertise variable is increased by one unit, the intention to buy food and beverage MSME products will increase. $32.1 \%$. The results of this study are supported by previous research where in 
Totoatmojo's research, Kumala Maharani [5] states that there is a positive and significant influence on the influence of celebrity endorsers on consumer purchase intentions on Instagram social media. From Celebrity Endorser, respondents see the aspect of the number of followers, belief namely the celebrity endorser, the number of likes of products marketed on social media, as well as the knowledge of celebrity endorsers who convince people to buy the promoted product.

Attractiveness, Trustworthiness and Expertise have a significant positive effect on the online purchase intention in food and beverage food and beverage of MSME products.

The results of the $\mathrm{F}$ test of Attractiveness, Trustworthiness and Expertise on the online purchase intention in food and beverage food and beverage of MSME products, show that the $\mathrm{f}$ value is 54,742 and the $\mathrm{p}$ value ( $\mathrm{sig}$ ) is 0,000 which is below 0.05 alpha $(0,000<0,05)$ which means that Attractiveness, Trustworthiness and Expertise simultaneously have a positive and significant effect on the online purchase intention in food and beverage food and beverage of MSME products.

\section{Conclusion}

Attractiveness of celebrity endorser has a positive and significant effect on the online purchase intention in food and beverage food and beverage of MSME products meaning that the increasing of attractiveness of celebrity endorsers will increase the online purchase intention in food and beverage food and beverage of MSME products

Trustworthiness on celebrity endorsers has a positive and significant effect on the online purchase intention in food and beverage food and beverage of MSME products, meaning that the increasing of Trustworthiness towards celebrity endorsers will increase the online purchase intention in food and beverage food and beverage of MSME products

Expertise on celebrity endorsers has a positive and significant effect on the online purchase intention in food and beverage food and beverage of MSME products, meaning that the increasing of Expertise towards celebrity endorsers will increase the online purchase intention in food and beverage food and beverage of MSME products

Attractiveness, Trustworthiness and Expertise have a significant positive effect on the online purchase intention in food and beverage of MSME products, meaning that the increasing of Attractiveness, Trustworthiness and Expertise towards celebrity endorsers will increase the online purchase intention in food and beverage food and beverage of MSME products

\section{Reference}

[1] F. . Zuari, H. Widayani, and R. D. Daniel, "Pengaruh Strategi Pemasaran Terhadap Penerimaan Bersih Restoran Omah Pincuk," in Proceeding PESAT, 2013, pp. 383389.

[2] S. Syuhada, "Analisis Perkembangan Unit Usaha dan Penyerapan Tenaga Kerja Serta Pengaruhnya Terhadap Pendapatan Keluarga Pada Usaha Mikro, Kecil dan Menengah Berbasis Pangan Olahan di Kecamatan Pelayangan Kota Jambi.," $J$. Penelit. Univ. Jambi Seri Hum., vol. 16, no. 1, pp. 23-28, 2014.

[3] N. M. M. Indraswari and K. A. S. Pramudana, "Pengaruh Kredibilitas Celebrity 
Endorser Dan Kewajaran Harga Terhadap Niat Beli Konsumen Wanita Pada Online Shop Produk Pakaian,” J. Bisnis Dan Ekon., vol. 3, no. 4, pp. 938-955, 2014.

[4] A. Djakasaputra, I. B. Hubner, T. Noval, S. Tinggi, and P. Pelita, "Pengaruh Celebrity Endorser Dan Brand Image Terhadap Purchase Intention Produk Kosmetik Etude House Pada Pelita Harapan Karawaci," Skylandsea, vol. 2, no. 2, pp. 251-256, 2018.

[5] K. M. T. Atmojo, The Celebrity Endorser (Selebgram) Effect toward Purchase Intention on Instagram Social Media. Yogyakarta: Communication Department, Universitas Gadjah Mada, 2013. 